\title{
INFLUENCE OF INSTAGRAM CONTENTS TOWARDS BUYING FOOD PRODUCTS INTEREST ON INSTAGRAM (A CASE STUDY OF BUYING INTEREST THROUGH THROUGH PROFESSIONAL CHEF'S INSTAGRAM POST ON PRESIDENT UNIVERSITY STUDENTS)
}

\author{
Natasya Putri Salsabila \\ Jony Oktavian Haryanto \\ Management, International Business Study, President University \\ natasyaputri.s@gmail.com \\ jony.haryanto@president.ac.id
}

\section{A R T I C L E I N F O}

\section{Article history:}

Received : 20 March 2021

Revised : 20 March 2021

Accepted : 29 March 2021

\section{cc) (i) (2)}

Keywords:

Instagram, purchase intention; food products; professional chef
DOI:

https://doi.org/10.33508/rima.v4i1.3085

\begin{abstract}
A B S T R A C T
Using Instagram for business activities became a specific activity among young people, especially students. One of the online businesses run by young people today was a food and beverage business, the other business was in the clothing and apparel field. The need for food products was increasing on Instagram users who preferred to make online purchases through Instagram. The content of a professional chef's Instagram account was one that influenced individuals to buy food or beverage products through Instagram social media. Professional chef was an interesting profession known by the public and it made young people interested in becoming a professional chef as one of the career professions. Professional chefs also used Instagram media for live career promotion and branding, food product promotions, recipes and even cooking course invitations. The main subject of this research was the Instagram account of a professional chef. The research sample was 218 President University students who had Instagram accounts and made online purchases on Instagram. Data collection used was questionnaires using quantitative research methods. Validity, reliability tests, data analysis used was SEM with SmartPLS. It found that verified Instagram accounts and the intention of following updated Instagram content had influenced the purchase intention of a product, but Instagram content and users' interest in following instagram accounts did not affect the purchase intention of a product.
\end{abstract}

\section{INTRODUCTION}

Instagram can be said as the biggest social media that has a huge amount of users, especially in Indonesia. In 2019, Instagram reached more than 60 million users, according to data submitted by the NapoleonCat social media marketing Analysis Company in Poland. It means that the total users have reached 22.4 of the Indonesian population. From these data, it is confirmed that Instagram is a vast and promising niche market to market and sell products, sell any product easily and quickly. With the market niche, Instagram usage reaches $79 \%$ (Jayani, 2020) of 16 to 64 years in Indonesia. Instagram is one of the most powerful social media platforms to promote business activities.

Social media marketing is a communication activity that uses electronic 
media (online) to attract consumers or companies in a variety of ways (images, writing, etc.) to raise awareness, image of companies and increase sales (Indika \& Jovita, 2017). According to HootSuit research in 2020, YouTube is the most widely used platform for social media users in Indonesia between 16 and 64 years of age. The percentage of users who accessed YouTube reached $88 \%$.

Comparing the statistical reports above those users of the more widely used YouTube, other reports show that social media is often used for online shopping via social media platforms such as Facebook and Instagram or the available marketplace. YouTube is a media-driven social media platform, such as television or video content provider sites. Internet users often use YouTube to watch impressions that they love or are looking for based on user interests and hobbies.

The survey conducted by the IDN Research Institute in cooperation with the Alvara Research Center in 12 major cities in Indonesia, entitled Indonesian Millennial Report 2019, was published in the journal Deloitte Indonesia Perspective (2019). It shows $94.4 \%$ of millennials in Indonesia have been connected to the Internet, and when redefined, Instagram users on millennials reach up to $33 \%$ of it. The existence of Instagram indirectly produces the new generation called the IG (Instagram) generation. Current millennials who become students are included in the above statistical data coverage. In this research, the author only focuses on the social media platform, Instagram.

A product that is currently popular to be marketed through social media is a food product. Foods are the primary human needs which are likely uploaded by Instagram users to be posted in their accounts. Based on the Indonesian Central Bureau of Statistics (BPS) e-commerce statistical data year 2019, food and beverage are in the first position of this business category in e-commerce is $27.85 \%$. With this data, food and beverage products are products that are often found in online businesses that are marketed through social media.

Table 1.1

Percentage of e-commerce Business

\begin{tabular}{|c|c|}
\hline Business category & 2018-2019 \\
\hline $\begin{array}{l}\text { Food and } \\
\text { beverage }\end{array}$ & 27,85 \\
\hline Clothing line & 22,11 \\
\hline $\begin{array}{l}\text { Digital product } \\
\text { (movie, music, } \\
\text { software) }\end{array}$ & 20,37 \\
\hline Service product & 20,83 \\
\hline $\begin{array}{l}\text { Others (ticketing, } \\
\text { voucher hotel, } \\
\text { etc.) }\end{array}$ & 8,84 \\
\hline
\end{tabular}

Due to many Instagram users who like to upload food photos, it is utilized by some people to sell food products, such as food manufacturers, small and medium businesses, even professional chefs. Hence, this phenomenon has made Instagram an incredibly promising social media. The content displayed on Instagram social media affects the buying and consuming interest of its users. The ability to process food ingredients into ready-to-serve food is excellent content. It has a multiplier factor in increasing self-promotion, marketing, and product selling offered to the followers.

Other professional chef activities such as organizing cooking courses, sharing secret recipes, live cooking on the TV show, even cooking competitions, can be one of the contents of a professional chef's Instagram. This content increases the attraction of the followers of professional Chef's Instagram account. Some of the followers might be interested in buying products offered or activities held. From this statement, it can be said that information seeking and evaluation is a series of acts that consumers do before making a purchase decision.

Based on the statement above, it can be explored that the strength of the content 
on Instagram greatly influences consumer's decision to buy the products offered on the Instagram account.

The contents have their uniqueness to attract the attention of the followers. By taking great photos, cooking tutorials, and cooking tips that are well managed; thus, it will trigger the followers to interact directly and motivate them to buy the products offered. Many more professional chef's Instagram accounts have content that promotes and markets their products or certain manufacturers' products in the principle of cooperative contracts. Cooperation between the product owners with a professional chef's account promotes a product called the term endorsement, which means supporting (support) or agreeing to something. The endorser delivers the artist's main product to advertise on the artist's Instagram account (Pratiwi, 2015). The artist in the context of this time is the professional chefs.

Talking about Instagram users, given its swift development, almost all university students have an Instagram account with a different intention, such as interacting with friends or buying some products. At President University, there are a lot of students who are utilizing Instagram to sell their products or even to buy some products. On the other side, currently, becoming a chef is an interesting profession for millennials. It's seen that the followers of a professional chef's Instagram account are mostly followed by younger generations. The first impression of being a chef is just about how to cook, working in a kitchen restaurant that was initially a regular job. This all became interesting content to be seen by the young users of Instagram.

The research done by Makhin (2016) concluded a positive influence and relationship between Instagram accounts with consumer buying interest. Another study by Kusuma and Sugandi (2018) mentioned the results of their research that Instagram social media's role can increase doughnut sales every month. Indika and Jovita (2017) concluded an influence between Instagram with the consumer's buying interest. Research is done by the sale of tourist tickets and food-place sales. With a wide range of scientific research and research on concepts that influence a product's buying interest and the various variables featured in this study, researchers wanted to display other types of variables from an Instagram account (as the selected social media platform) of the professional chef's Instagram account as the main group variable.

Content that contains interesting product information quickly attracts interest in purchasing a product (Makhin, 2016). The decision to buy food or beverage products on Instagram users after seeing content is also influenced by an individual attitude of Instagram users (Anjaskara, 2016). The theory used in this study is the principle of purchase interest made by consumers due to the influence of the phenomenon of attraction from advertising content.

This interest is based on the AIDA model's focus theory developed by E. St. Elmo Lewis in 1989 (Johar, Kumadji, \& Mawardi, 2015). The use of AIDA model principles has been extensive in business science and communication science. One explanation of the AIDA model for business science, especially marketing, in the research report conducted by Li \& Yu (2013), explains how AIDA's concept can market the bank products with the help of social media and the internet with the target of business students.

This study was conducted to identify precursor factors that influence interest in the purchase of Instagram products subjects belonging to professional chefs with President University students as followers and users of Instagram. Research objectives this study; (1) To know whether an Instagram account (verified account of a professional chef) has a positive influence on product buying interest, (2) To know whether Instagram content has a positive influence on product buying interest, (3) To know whether the interest in following an 
Instagram account has a positive influence on product buying interest, (4) To know whether the intention of following the update from Instagram content has a positive influence on the product buying interest, (5) To know whether a verified Instagram account has a positive influence on the intention of following the update from Instagram content, (6) To know whether Instagram content has a positive influence on the intention of following the update from Instagram content, (7) To know whether the interest in following an Instagram account has a positive influence on the intention of following the update from Instagram content.

\section{LITERATURE REVIEW}

All major social media use digital platforms. According to Manning (2014), two common characteristics help to define social media; (1) Social media allows certain types of participation, social media is never completely passive. (2) Social media, in line with their participatory nature, involves interaction. These interactions may be formed between friends, family, or acquaintances of new people who share common interests, or even general contact circles.

According to (Kaplan \& Haenlein, 2010) in Horizon Business Magazine, there are six types of social media; (a) Website collaboration: a kind of website which is allowing its users to be able to change, add, or subtract content contained on the website, for example, Wikipedia, forum websites, (b) Blogs and microblogging: users are free in expressing something on social media, such as making status updates about personal experiences, feelings, statements, and opinions, self-expression, for example, Twitter, BlogSpot, WordPress, (c) Content: this type makes media content information shared directly and free, whether it is media in the form of videos, eBooks, images, sounds, and others. For instance, YouTube, (d) Social networking sites: these applications allow users to stay connected by making personal information to be able to accessed or viewed by others. Personal information can be like photo documentation. This social media type is Instagram and Facebook, (e) Virtual Game: it is a digital gaming platform in which users can appear in the form of a selected avatar and interact with other people in the real world, for instance, online games, (f) Virtual Social World: it allows users to feel life in a virtual world, connect to others who are equally familiar with each other in real life, for example, second life, alter world.

Social media, such as Instagram, Facebook, Twitter and YouTube, have a number of business benefits instead of using conventional media as promotional media. The importance of social media use as a promotional medium is also described according to (Kshetri \& Jha, 2016); the use of electronic media to a brand is a communication that conveys information about suppliers and the use of products to consumers through online shopping using web-based technologies such as Facebook, Twitter, Instagram and various other social media.

The effectiveness of promotional media in a professional chef's Instagram account related to buying interest can be measured through the AIDA model (Attention, Interest, Desire, and Action). E. St. Elmo Lewis first developed it in 1898 (Li \& Yu, 2013). According to Johar et al (2015) before the purchase there are stages called Hierarchy of Effect (HOE). Hierarchy-of-effect is the degree of influence advertising has on consumers. AIDA (Attention, Interest, Desire, Action) is the most famous Hierarchy of Effect Theory. In conclusion, an advertisement can be said to be an effective advertisement when it has reached AIDA.

The stages of AIDA can be noticed directly by consumers who see ads, if in the online context the messengers can know firsthand how the response from consumers without seeing the expression of the face, or the movements of the consumer's body in response to the advertisement, through 
online media one of which is the social media Instagram.

In the use of Instagram, there are several rules set for the user in the Term of Use, including the requirement to be at least 13 years old or older to create an Instagram account. There are also restrictions on violent, nude, partially nude, or sexually suggestive posts. Users are granted ownership of the content on Instagram. Instagram does not claim ownership rights for text, files, images, photos, videos, sounds, artwork, writings, applications, or other materials posted by users.

The chef profession appeared in the 19th century earlier and was called by 'Cook' or 'master of Cook'. Afterward, Auguste Escoffier created the organizing and hierarchy of work in the kitchen. According to Lastariwati et al., (2019), Chef in English is adapted and abbreviated from the French word, that is, Chef de cuisine, which means head chef. The word 'chef' is usually used in professional jobs in the hospitality sector. According to Oxford Dictionary Online (2019), the term chef is a professional cook or commonly referred to as a chief cook in a restaurant or hotel. However, there is no professional organization that determines exactly who is entitled as 'Chef'.

In a hierarchical system in restaurants and hotels that employ a lot of staff, the chef's term is not merely used for the highest position in the kitchen (Orami, 2019), there are different level position functions in the hotel's system organization or restaurant, including; (a) Chef de cuisine (executive chef/chef manager/head chef/master chef): people in charge of all the activities related to the kitchen, (b) Souschef de cuisine (under-chef): This position is used for deputy and right-hand executive chef or head chef, (c) Chef de partie (senior chef): Senior chef or Chef de partie has responsibility for arranging one section devoted to a particular dish, (d) Commis (junior chef): Junior chef work at a specific station under the direction of Chef de Partie. In addition, many other kitchen positions relate to certain parts, such as Saute chefs (specialize in preparing sauces) and pastry chefs (specialize in making a variety of cakes and desserts).

Knowing all the capabilities of Instagram's social media has made every individual from various fields, including culinary fields, a professional chef utilizing Instagram to develop their existence and share information in the culinary world. One of the features on Instagram confirms that the account is accountable based on the individual profile, and the profession being held is the "Verified Account" feature.

The sign of an account category "Verified Account" is the presence of a badge that is illustrated or marked with a blue "checklist". As explained in the Instagram help desk page, the checked badge is a checkmark next to the name of the Instagram account in the search and profile. This means that Instagram has confirmed the authenticity of an account that represents a public figure, a celebrity or a global brand.

According to Votipka et al., (2019), verified accounts are often reserved for well-known organizations and individuals and are indicated by badges $(\sqrt{ })$ that appear next to the account owner's name. The main point is a verified Instagram account is intended to allow Instagram users to easily distinguish the original from the public interest and those included in a parody or fraudulent account or an imitation. One of the verified account signs on Instagram's excess advantages is increasing public trust in the Instagram account.

Buying interest is an action by a consumer before making a product purchase decision. Buying interest is a stage of consumer interest in a product, and a buying interest comes after consumer awareness and perception of a particular product (Indika \& Jovita, 2017). According to Permatasari and Kuswadi (2017), the buying interest is influenced by social media conducted through consumer perception of the product in their research paradigm. The 
search by Kristyatmoko and Andjarwati (2013) said that interest in buying was measured by learning more about the product, believing that the product is right for the consumer, and maybe buying the product.

Consumer interest grows due to a motive based on using a product and making the consumer's interesting process very important. It is explained in the research journal (Haryanto \& Hartanto, Display Influence, Brand Trust, Brand Familiarity, Price Perception of Unplanned Purchase and Purchase Intention, 2012) that in general, four indicators influence buying interest; (1) Transactional interests, explaining a person's tendency to purchase products, (2) Reference interests, explaining one's tendency to refer products to others, (3) Preference interests describing the behavior of a person who has a primary preference for a product, (4) Exploratory interests, explaining the behavior of someone who is always looking for information about the product they are interested in, and seeking information to support its positive nature.

In the research journal (Haryanto \& Hartanto, Display Influence, Brand Trust, Brand Familiarity, Price Perception of Unplanned Purchase and Purchase Intention, 2012) it is also explained further that one of the factors that influences buying interest is a display. The display is in the promotion of point of purchase. Quoting from Foster (2008) in the journal research Haryanto and Hartanto (2012), the displayed definition is the desire to buy something that is not driven by a person but driven by attractiveness or vision by others feelings. In this study, Instagram content is a type of display that affects consumers' buying interests.

The dynamics of the relationship between social media marketing and the establishment of buying interest products from the literature explanation above and the concept of AIDA, interest decisionmaking stages Kotler's theory ultimately leads to the concept of an interaction between humans itself as Instagram users either as account owners or followers of Instagram accounts. Interactions on social media occur when users and companies communicate or exchange information (Maoyan, Zhujunxuan, \& Sangyang, 2014). In the research conducted by Haliyani (2018) interactions on Instagram content became influential factors in buying interest.

\section{RESEARCH METHOD}

Quantitative methods are chosen by the researcher to determine the significant relationship between the social facts and the variables used in the research, this research is a survey method with questionnaires as a data retrieval tool. The questionnaire indicator used in this study adopts from previous research conducted by Makhin (2016) in Jogjakarta and adopted from Indika \& Jovita research (2017) on the phenomenon of tourist ticket sales effect promotion Instagram account. This research is explorative and descriptive, descriptive statistics summarize, present, and describe data in an easy-to-read form to provide complete information (Muhson, 2012).

The sampling of this research based on the concept of Malhotra (2017) begins with; define the target population, this research population was president University's students. Convenience sample seeks to obtain a convenient sample of elements; respondents are chosen because at the right time they are in the right place. The next stage determines the size of the samples. The samples in this study suggested at least 200 samples. To get much more valid research results and reliable samples can be more than 200 respondents (Malhotra, 2017).

The validity test and reliability test are necessary to determine the questionnaire quality to be used as testing for research variables. To validate the hypothesis of the variable tools used during this analysis on a partial least square (PLS) basis by using the structural equation modeling (SEM). With significance ( $\alpha$ ) of 5\% 
and obtained T-table $=1.96$, the provision of T-statistic $>1.96$ considered significant, it was decided to use the SmartPLS program for the data analysis method.

\section{RESULT AND DISCUSSION}

The respondent's sample was President University students as Instagram users. From questionnaires distributed by researchers, 225 respondents were obtained, but after the elimination process of invalid questionnaire data, it was obtained only by 218 respondents.

\section{Table 1.2}

\section{Gender Characteristic}

\begin{tabular}{lll}
\hline $\begin{array}{l}\text { Gender } \\
\text { (Q2) }\end{array}$ & Frequency & $\%$ \\
\hline Male & 90 & $41 \%$ \\
Female & 128 & $59 \%$ \\
Total N & 218 & $100 \%$
\end{tabular}

Source: Primary data, processed in 2020

Table 1.2 indicated that the respondents' gender distribution composition of 218 respondents were (59\%) women and men $(41 \%)$. This data description was in accordance with the results of data submitted by the NapoleonCat social media marketing Analysis Company in Poland about Instagram users. There were $81,770,000$ Instagram users in Indonesia in November 2020 It was $29.8 \%$ of its entire population, and $52.5 \%$ of them were women.

Respondents' characteristics of composition with Instagram (shown in table 1.3 and 1.4) were very high. It was recorded that absolutely $100 \%$ of President University students had Instagram accounts and routinely used Instagram with various usage periods. It is in accordance with the questionnaire question no. 5 .

The largest percentage of Instagram usage was $44 \%$ over $1-2$ years. It also recorded that $100 \%$ of respondents admitted their Instagram account used for business activities, having purchased products through Instagram, and following the Instagram account of a professional chef.

Table 1.3

Student Activities part 1

\begin{tabular}{|c|c|c|c|c|}
\hline \multirow[t]{2}{*}{ Answer } & \multicolumn{2}{|c|}{$\begin{array}{l}\text { Have an IG } \\
\text { account } \\
\text { (Q4) }\end{array}$} & \multicolumn{2}{|c|}{$\begin{array}{l}\text { The period of } \\
\text { using IG (Q5) }\end{array}$} \\
\hline & $\Sigma$ & $\%$ & $\Sigma$ & $\%$ \\
\hline Yes & 218 & $100 \%$ & & \\
\hline No & 0 & 0 & & \\
\hline$>2$ years & & & 57 & $26 \%$ \\
\hline 1-2 year & & & 96 & $44 \%$ \\
\hline$<1$ year & & & 65 & $30 \%$ \\
\hline Total N & 218 & $100 \%$ & 218 & $100 \%$ \\
\hline
\end{tabular}

Table 1.4

Student Activities part 2

\begin{tabular}{|c|c|c|c|c|c|c|}
\hline \multirow[t]{2}{*}{$\begin{array}{l}\text { Answe } \\
r\end{array}$} & \multicolumn{2}{|c|}{$\begin{array}{l}\text { Having an } \\
\text { IG for } \\
\text { Business } \\
\text { (Q6) }\end{array}$} & \multicolumn{2}{|c|}{$\begin{array}{l}\text { Buying } \\
\text { products } \\
\text { on IG } \\
\text { (Q8) }\end{array}$} & \multicolumn{2}{|c|}{$\begin{array}{l}\text { Following } \\
\text { Profession } \\
\text { al Chef's } \\
\text { IG Account } \\
\text { (Q9) }\end{array}$} \\
\hline & $\Sigma$ & $\%$ & $\Sigma$ & $\%$ & $\Sigma$ & $\%$ \\
\hline \multirow[t]{2}{*}{ Yes } & 21 & 100 & 21 & 100 & 21 & 100 \\
\hline & 8 & $\%$ & 8 & $\%$ & 8 & $\%$ \\
\hline No & 0 & 0 & 0 & 0 & 0 & 0 \\
\hline
\end{tabular}

Table 1.5

Types of Business Activities on Instagram

\begin{tabular}{lll}
\hline Business Sector (Q7) & Frequenc & (\%) \\
& $\mathbf{y}$ & \\
\hline Food and Beverage & $\mathbf{7 0}$ & $\mathbf{3 2 \%}$ \\
Clothing Line & $\mathbf{7 0}$ & $\mathbf{3 2 \%}$ \\
Service & 41 & $19 \%$ \\
Other & 37 & $17 \%$ \\
Not Answered & 0 & $0 \%$ \\
Total N & 218 & 100 \\
& & $\%$
\end{tabular}

Source: Primary data, processed in 2020 
President University students used Instagram accounts for business activities (table 1.5), that the most conducted businesses were food and beverage products and clothing line business (32\%), service business (19\%) and other businesses (17\%). It's in line with the data submitted by the Central Statistics Agency of Indonesia (BPS) in which e-commerce statistical data year of 2019 stated that food and beverage were in the first position of business category in e-commerce with $27.85 \%$ and followed by the clothing line with $22.11 \%$ (BPS, 2019).

This data explained that online business activities had developed well at the productive young age level represented by students, this data also described that social media could also increase young generations' entrepreneurial activities.

Table 1.6

The Instagram Accounts of Professional Chefs Followed by Respondents

\begin{tabular}{lll}
\hline $\begin{array}{l}\text { Professional } \\
\text { Chef's Instagram } \\
\text { Account }\end{array}$ & $\begin{array}{l}\text { Number } \\
\text { of } \\
\text { Responde } \\
\text { nts Who } \\
\text { Followed }\end{array}$ \\
\hline $\begin{array}{l}\text { Chef Arnold } \\
\text { Poernomo }\end{array}$ & 87 & $40 \%$ \\
Chef Juna & 112 & $51 \%$ \\
Chef Marinka & 109 & $49 \%$ \\
Chef Chitra & 99 & $45 \%$ \\
Chef Vindex & 103 & $47 \%$ \\
Chef Prisciliya & 77 & $35 \%$ \\
Princessa & & $12 \%$ \\
Other Chef & 27 & \multicolumn{2}{c}{ Source: Primary data, processed in 2020}
\end{tabular}

The respondents were free to follow any Instagram accounts, including the professional chef's Instagram accounts (shown in table 1.6). Chef Juna (@junarorimpandeyofficial) was the most popular male chef, with $51 \%$ of total respondents. It means that all respondents $(\mathrm{N}=218)$ as many as $51 \%$ of respondents knew Chef Juna based on the Instagram account followed by them. Chef Marinka (@rinrinmarinka) was the most popular female chef, with $49 \%$ of respondents knowing about chef Marinka, other chefs, respondents gave a choice of $12 \%$. It means that respondents had followed other professional chef accounts even though the professional chef's name was not included in the questionnaire.

The choice of Instagram account followed by respondents indicated the brand equity and brand awareness of Instagram accounts. In this research, brand awareness focused on a professional chef's Instagram account's on their personal branding in managing their content. Brand awareness was closely related to the frequency of the advertisement received and processed by the consumer (Haryanto \& Andriyanto, Analisis Pengaruh Internet Marketing Terhadap Pembentukan Word of Mouth dan Brand Awareness Untuk Memunculkan Intention to Buy, 2010).

Table 1.7

Validity and Reliability

\begin{tabular}{|c|c|c|c|}
\hline Variable & (CA) & (CR) & AVE \\
\hline $\begin{array}{l}\text { Verified Account } \\
\text { (X1) }\end{array}$ & $\begin{array}{l}0,67 \\
7\end{array}$ & $\begin{array}{l}0,59 \\
7\end{array}$ & $\begin{array}{l}0,51 \\
1\end{array}$ \\
\hline Content (X2) & $\begin{array}{l}0,59 \\
7\end{array}$ & $\begin{array}{l}0,52 \\
2\end{array}$ & $\begin{array}{l}0,50 \\
5\end{array}$ \\
\hline $\begin{array}{l}\text { Interest in } \\
\text { following a } \\
\text { professional chef's } \\
\text { Instagram account } \\
\text { (X3) }\end{array}$ & $\begin{array}{l}0,54 \\
4\end{array}$ & $\begin{array}{l}0,54 \\
3\end{array}$ & $\begin{array}{l}0,51 \\
1\end{array}$ \\
\hline $\begin{array}{l}\text { Intention to } \\
\text { Follow Update } \\
\text { Content (X4) }\end{array}$ & $\begin{array}{l}0,62 \\
1\end{array}$ & $\begin{array}{l}0,73 \\
5\end{array}$ & $\begin{array}{l}0,53 \\
3\end{array}$ \\
\hline Buying Interest $(\mathrm{Y})$ & $\begin{array}{l}0,69 \\
1\end{array}$ & $\begin{array}{l}0,58 \\
6\end{array}$ & $\begin{array}{l}0,52 \\
1\end{array}$ \\
\hline
\end{tabular}

Calculation result with the SEM-PLS modeling method, it was obtained that the validity test referred to AVE coefficient, AVE measure $>0.5$, it can be mentioned that the questionnaire on the construction of modeling those variables was statistically valid. Table 1.7 generally shows an idea that all variables used in this study have 
reliability levels above $50 \%$. In general, this research's construction variables with research instruments (questionnaires) are quite valid, with a total sample obtained above 200 samples.

\section{Table 1.8}

\section{Hypothesis Test}

\begin{tabular}{llll}
\hline $\begin{array}{l}\text { Hypo } \\
\text { thesi } \\
\text { s }\end{array}$ & $\begin{array}{l}\text { Hypothetical } \\
\text { Statement }\end{array}$ & $\begin{array}{l}\text { P Values } \\
\text { T Statistics }\end{array}$ & $\begin{array}{l}\text { Acceptable / } \\
\text { Rejected }\end{array}$ \\
\hline H1 & $\begin{array}{l}\text { Verified Instagram } \\
\text { accounts have a }\end{array}$ & $0.008<0.0$ & Acceptable \\
& $\begin{array}{l}\text { positive influence on } \\
\text { product buying } \\
\text { interest }\end{array}$ & 2.671 & \\
& & & \\
& & & \\
\end{tabular}

\begin{tabular}{llll}
\hline H2 & The content of the $0.361>0.0$ & Rejected \\
professional chef's 5 & \\
Instagram account 0.915 & \\
has a positive & \\
influence on product \\
buying interest
\end{tabular}

\begin{tabular}{|c|c|c|c|}
\hline H3 & $\begin{array}{l}\text { Interest in following a } \\
\text { professional chef's } \\
\text { Instagram account } \\
\text { has a positive } \\
\text { influence on product } \\
\text { buying interest }\end{array}$ & $\begin{array}{l}0.052>0.0 \\
5 \\
1.948\end{array}$ & Rejected \\
\hline H4 & $\begin{array}{l}\text { The intention of } \\
\text { following the update } \\
\text { from Instagram } \\
\text { content has a positive } \\
\text { influence on product } \\
\text { buying interest }\end{array}$ & $\begin{array}{l}0.000<0.0 \\
5 \\
7.783\end{array}$ & Acceptable \\
\hline H5 & $\begin{array}{l}\text { Verified Instagram } \\
\text { accounts has a } \\
\text { positive influence the } \\
\text { intention of following } \\
\text { the update from } \\
\text { Instagram content }\end{array}$ & $\begin{array}{l}0.000<0.0 \\
5 \\
4.942\end{array}$ & Acceptable \\
\hline H6 & $\begin{array}{l}\text { The content of the } \\
\text { professional chef's } \\
\text { Instagram account } \\
\text { has a positive } \\
\text { influence the } \\
\text { intention to follow the } \\
\text { updated content }\end{array}$ & $\begin{array}{l}0.008<0.0 \\
5 \\
3.873\end{array}$ & Acceptable \\
\hline H7 & $\begin{array}{l}\text { Interest in following a } \\
\text { professional chef's } \\
\text { Instagram account } \\
\text { has a positive } \\
\text { influence the } \\
\text { intention to follow the } \\
\text { updated content }\end{array}$ & $\begin{array}{l}0.001<0.0 \\
5 \\
3.458\end{array}$ & Acceptable \\
\hline
\end{tabular}

Source: conducted by researcher using SmartPLS
The perceptions and opinions about verified Instagram accounts (X1) affected product buying interests described by Tjahjono et al. (2013). It was explained that one of the psychological aspects that influence buying interest was perception and opinion about an advertisement or type of social media used, whether it can be trusted or not based on the perception of authentic social media advertising source. It also stated by Rahima (2018) that verified accounts were important as authentic proof of a public figure.

According to Votipka et al. (2019), accurate information obtained from verified social media accounts could influence people's perceptions of user-generated content. An individual's trust level was slightly better to make certain decisions after seeing accurate information from verified accounts.

The hypothesis test results on the content of Instagram account (X2) strengthen the research statement conducted by Haryanto et al. (2010), which stated that dimensions in Instagram account content were part of content marketing form in the internet marketing era has no positive effect on buying interest.

Keywords in (X2) variable (Instagram account's content) to influence the buying interest of product (Y) should have the consistency in creating the content was in accordance with Vinerean (2017) which explained that content marketing is a strategic marketing approach that aims to generate and distribute valuable, relevant, and consistent content to attract and retain a clearly-defined client.

The results of the hypothesis test on interest to follow a professional Chef's Instagram account (X3) strengthen the research statement conducted by Johar et al., (2015) that in the concept of AIDA (Attention, Interest, Desire, Action) on online advertising media including social media advertising, the idea of Action does not influence the effectiveness of social media advertising. 
Other factors make individuals able to perform action attitudes on the influence of social media advertising, especially to make a buying interest, the most important of which are individual psychological factors, among others; motivation, perception, learning, and beliefs and attitudes (Lautiainen, 2015). Theoretically, this was in accordance with $\mathrm{Li}$ and $\mathrm{Yu}$ (2013), which was described the pyramid upside down the concept of AIDA, that the decision of Action at the very bottom showed the main concept of AIDA more at the stage of Attention, Interest, Desire, it is aimed at the information or the product's needs, and then there was an interest in making it a reference for information to be followed.

From the first attempt of the intention of following the update from Instagram content (X4) construction proofing on variable verified account (X1), content Instagram account (X2), and interest to following Instagram account (X3), the variable $\mathrm{X} 4$ positively impacted variable $\mathrm{Y}$ (buying interest). Therefore, it can be explained further that from this variable (X4), the concept of intention to follow update content correlation based on content produced on social media positively influential in two dimensions of brand equity formation, namely brand loyalty and quality perception (Indriani, 2015).

Keywords on the intention to follow update content (X4) were the consistency of updated content on Instagram accounts. It would positively influence the buying interest behavior of individuals who used Instagram accounts since updated content will always form personal-brand awareness. Brand awareness was closely linked to the frequency of advertising received and processed by the consumer. Haryanto et al. (2010) found that the more famous the products, the more likely they to be selected and purchased by consumers.

Table 1.9

\section{R-square Construction Model}

Variable R-square

\begin{tabular}{l}
\hline $\begin{array}{l}\text { Intention to Follow Update } \\
\text { Content }(\mathrm{X} 4)\end{array}$ \\
\hline Buying Interest $(\mathrm{Y})$ \\
Source: conducted by researcher \\
using SmartPLS
\end{tabular}

In this SEM analysis model shown in table 1.9, the R-square value is obtained by 0.426 for variable $\mathrm{X} 4$ (Intention to Follow Update) and 0.461 for variable $\mathrm{Y}$ (Buying Interest). R-square is used to indicate the determinant's coefficient of the extent to which a construct can explain the model. This construct explains that the variable $\mathrm{X} 4$ as one of the intervening variables can be a determinant supporting variable $\mathrm{X} 1, \mathrm{X} 2$, and $\mathrm{X} 3$ against variable $\mathrm{Y}$. However, if there is no variable $X 4$, then the determination of variable $\mathrm{X} 1, \mathrm{X} 2, \mathrm{X} 3$ against variable $\mathrm{Y}$ is higher (0.461).

\section{CONCLUSION}

Based on the research results, it can be concluded several things;

(1) A verified Instagram account has a positive impact on a product's buying interest. In this case, it is a verified Instagram account of a professional chef. Verified accounts form good opinions and perceptions for Instagram social media users. (2) The contents of a professional chef's Instagram account do not positively influence a product's buying interest. Nevertheless, when the Instagram account contents are updated properly in a certain period of time, it will be a supporting factor affecting the product's buying interest. (3) The concept of interest in following a professional chef's Instagram account does not positively influence a product's buying interest. Other supporting factors influence the buying interest of a product. It is one of the main psychological factors of Instagram social media users. (4) The intention to follow the updated Instagram account that produces positive content will increase the positive influence on the product's buying interest. Content that updates properly will create brand awareness, such as the personal branding of professional chefs' 
Instagram account. (5) Verified Instagram account, Instagram account content, and interest were significant concepts that support the intention to follow the Instagram account. It proves that the need for content on Instagram is very high.

\section{IMPLICATION}

To improve the use of Instagram as a promotional medium and attract interest in buying a product, as applied implications can be done to; using social media for positive and rewarding things. The implications of using Instagram social media are very large when it is used for business purposes and as an effective promotional medium. Creating content innovations for social media is very important to increase the buying interest in products offered. Any business opportunity is always available by utilizing social media in this era. Avoid using any social media, including Instagram, only for things that are not productive or unlawful. In this era, crimes using social media are increasingly prevalent, and this should be an ongoing education for every individual citizen to obey the rule of law, especially regarding the rule of law governing the use of social media (Internet and Electronic Transactions Act - ITE Law).

Chefs or other professions need to use their Instagram accounts with good and measurable management. Good creation and well-updated content will increase personal selling value, and then it will create brand awareness on Instagram accounts. If the person selling value increases, the verified account process will be easier. It is caused by the public's trust that a verified account is a source of information needed by each individual of Instagram's social media user. Verified accounts will increase social media users' buying interest and then order a product offered on Instagram account content.

Limitations of research and agenda of future research
In the research that has been done, some limitations of existing research; (1) Only the Instagram accounts of professional chefs who have been famous in advance are researched. This causes respondents to be unable to compare a famous professional chefs' Instagram account content with other professional chefs who may be known through a fairly well-known restaurant or café business. (2) There are sentences in the questionnaire that may be poorly understood by respondents. It is expected that the next study can use clearer sentences. (3) The author only searches professional chef Instagram social media, Instagram content, Instagram user attitudes, and interest in buying products. Hopefully, in the next research, other variables such as celebrity Instagram account or better known as celebgram, promotions displayed, and other things. Instagram's concept is very dynamic and continues to develop following the advancement of technology and science in economics, management, and business.

\section{REFERENCE}

Anjaskara, D. I. (2016). Pengaruh Sikap Pada Media Sosial Instagram Terhadap Minat Beli Produk Kecantikan Melalui Instagram. Yogyakarta: Fakultas Ilmu Sosial dan Ilmu Politik Universitas Muhammadiyah Yogyakarta.

BPS. (2019). Statistik E-Commerce 2019. Jakarta: Badan Pusat Statistik Indonesia.

Daniel Votipka; Micah Sherr; Michelle L. Mazurek; Tavish Vaidya. (2019). Does Being Verified Make You More Credible? CHI Conference on Human Factors in Computing Systems Proceedings , 1-13.

Haliyani, F. P. (2018). Pengaruh Social Media Marketing Terhadap Purchase Intention Pada Starbucks Indonesia. Jurnal Ilmiah Fakultas Ekonomi Bisnis Universitas Brawijaya.

Haryanto, J. O., \& Andriyanto, R. D. (2010). Analisis Pengaruh Internet 
Marketing Terhadap Pembentukan Word of Mouth dan Brand Awareness Untuk Memunculkan Intention to Buy. Jurnal Manajemen Teknologi, 20-35.

Haryanto, J. O., \& Hartanto, A. (2012). Display Influence, Brand Trust, Brand Familiarity, Price Perception of Unplanned Purchase and Purchase Intention. Proceeding for Call Paper Pekan Ilmiah Dosen Universitas Kristen Satya Wacana, 261282.

Indika, D. R., \& Jovita, C. (2017). Media Sosial Instagram Sebagai Sarana Promosi Untuk Meningkatkan Minat Beli Konsumen. Jurnal Bisnis Terapan.

Indriani, S. (2015). Pengaruh Social Media Marketing Terhadap Pembentukan Purchase Intention Dan Customer Equity. Indonesia Journal of Entrepreneurship, 66-79.

Jayani, D. H. (2020, 02 26). Retrieved from katadata.co.id: https://betadataboks.katadata.co.id/datapublis h/2020/02/26/10-media-sosialyang-paling-sering-digunakan-diindonesia

Johar, D. S., Kumadji, S., \& Mawardi, K. (2015). Pengaruh AIDA (Attention, Interest, Desire, Action) Terhadap Efektivitas Iklan Online. Jurnal Administrasi Bisnis Vol. 26 Universitas Brawijaya Malang.

Kaplan, A., \& Hainlein, M. (2010). Users of the World, Unite! The Challenges and Opportunities of Social Media. Horizon Business Magazine, 59-68.

Kotler, P., \& Keller, K. L. (2016). Marketing Management (Global Edition) 15th Edition. New Jersey: Pearson Pretice Hall, Inc.

Kristyatmoko, Y., \& Andjarwati, A. L. (2013). Pengaruh Persepsi Kualitas dan Harga Terhadap Minat Beli Tablet SAMSUNG GALAXY TAB. Jurnal Ilmu Manajemen.
Kshetri, A., \& Jha, B. (2016). Online Purchase Intention: A Study of Automobile Sector in India. Rev. Integr. Bus. Econ. Res, 35-59.

Kusuma, D. F., \& Sugandi, M. S. (2018). Strategi Pemanfaatan Instagram Sebagai Media Komunikasi Pemasaran Digital Yang Dilakukan Oleh Dino Donuts. Bandung: Fakultas Komunikasi dan Bisnis Universitas Telkom.

Lastariwati, B., Mahfud, T., \& Pardjono. (2019). Chef's Competency As A Key Element In Food Tourism Success: A Literature Review . GeoJurnal of Tourism and Geosites, 1057-1071.

Lautiainen, T. (2015). Factors Affecting Consumers' Buying Decision in The Selection of a Coffee Brand. Faculty of Business Administration Saiima University.

Li, J., \& Yu, H. (2013). An Innovative Marketing Model Based on AIDA: A Case from E-bank Campusmarketing by China Construction. iBusiness Journal, 47-51.

Makhin, A. (2016). Pengaruh Akun Instagram JAVAFOODIE Terhadap Minat Beli Konsumen (Analisis Regresi Sederhana pada Pengunjung Studio Kopi di Yogyakarta). Yogyakarta: Fakultas Ilmu Sosial dan Humaniora Universitas Islam Negeri Sunan Kalijaga.

Malhotra, N., Nunan, D., \& Birks, D. (2017). Marketing Research: An Applied Approach 5th Edition. New York: Pearson Education.

Manning, J. (2014). Definition and Classes of Social Media. Encyclopedia of Social Media and Politics, Publisher: Sage Publications, 1158-1162.

Maoyan, Z., \& Sangyang. (2014). Consumer Purchase Intention Research Based on Social Media Marketing. International Journal of Business and Social Science, 92-97.

Muhson, A. (2012). Pelatihan Analisis Statistik Dengan SPSS. Yogyakarta: UNY. 
NapoleonCat. (2019, 12). Retrieved from napoleoncat.com:

https://napoleoncat.com/stats/inst agram-users-in-indonesia/2019/12

NapoleonCat. (2020, 11). Retrieved from Napoleoncat.com:

https://napoleoncat.com/stats/inst agram-users-in-indonesia/2020/11

Orami. (2019, June 11). Orami Parenting. Retrieved from parenting.orami.co.id:

https://parenting.orami.co.id/mag azine/gelar-chef-sebenarnya-untuksiapa/

Permatasari, A., \& Kuswadi, E. (2017). he Impact of Social Media on Consumers' Purchase Intention: A Study of Ecommerce Sites in Jakarta, Indonesia. Integrative Business and Economics Research, 321-335.

Perspective, D. I. (2019). Generasi Milenial dalam Bagi Sumber Daya Manusia Indonesia atau Ancaman ? Jakarta: Deloitte Indonesia Magazine.

Pratiwi, T. R. (2015). Terpaan iklan, penggunaan celebrity endorser dan minat beli (Studi Pengaruh Terpaan Iklan Kaffah di Instagram dan
Penggunaan Celebrity Endorser pada Iklan Kaffah di akun @kaffahbysj terhadap Minat Beli pada Follower Akun @kaffahbysj). Jurnal Komunikasi Massa.

Rahima, P. (2018). Pengaruh Celebrity Endorser di Media Sosial Instagram Dalam Promosi Produk Hijab Terhadap Minat Beli Konsumen. Seminar Nasional dan Call for Paper: Manajemen, Akuntansi dan Perbankkan, 50-60.

Riyanto, A. D. (2020, 11). Andi Link. Retrieved from andi.link: https:/ / andi.link/hootsuite-we-aresocial-indonesian-digital-report2020/

Tjahjono, A., Semuel, H., \& Brahmana, R. (2013). Analisis Marketing Mix, Lingkungan Sosial, Psikologi Terhadap Keputusan Pembelian Online Pakaian Wanita. Jurnal Manajemen Pemasaran Universitas Petra Surabaya.

Vinerean, S. (2017). Content Marketing Strategy. Definitions, Objective and Tactics. Expert Journal of Marketing Vol 5, 92-98. 